\title{
PRESENT APPLICATION OFRESOURCE MANAGEMENT IN PREFABRICATED AND IN-SITU CONSTRUCTION
}

\author{
V.Yuvaraj ${ }^{1}$ and R.Dharman ${ }^{2}$, \\ ${ }^{1}$ PG Scholar, M.E Construction Engineering and Management, \\ ${ }^{2}$ Assistant Professor, Department of Civil Engineering, \\ Shree Venkateshwara Hi-Tech Engineering College, Gobi, Tamil Nadu, India.
}

\begin{abstract}
Currently, prefabricated building plays a leading role in construction. Mounting with the standardization and mechanization, Prefabrication has brought an extensive transformation in the construction industry around the world. Moreover the associated advancements to the local construction industry with the espousal of more mechanization, intelligent management systems and computer aided manufacturing; the wide-ranging use of prefabrication also contributes to sustainable development by means of cleaner and more resources saving production process. The main aim of this paper is to present a prefabricated construction based on time and cost utilization over than in-situ construction. Also forecast the general idea about the development and application of prefabrication method in the construction of large-scale and high-rise buildings. The factors like time and cost are analyzed in normal construction and in prefabricated construction companies. The results are shown by using management software tools.
\end{abstract}

\section{KEYWORDS}

In-situ construction, prefabricated construction, Quality, Time, Cost.

\section{INTRODUCTION}

For many years prefabrication has been used comprehensively and commonly over the world wide. The manufacture of building components are often illustrated by the terms such as prefabrication, pre-assembly, system building, industrialized buildings and modularization which are constructed on any like on site/off-site in an industrial unit covering modular, manufactured and pre-cut/pre- engineered systems. Although the conditions/terms, are normally used correspondingly, their specific definitions depend deeply on the users' experience and indulgent, which differ from countries to countries. In this paper, prefabrication is chosen with extra prominence on the building components which are made off-site in an industrial unit. Off-site fabrication is an area of international significance and provides an efficient construction technique in terms of time, quality, cost, productivity, safety and function. It is adopted globally as the ultimate resources of producing an enormous range of elements from cladding units, structural members and bathrooms to fully-finished modular buildings.

A General Review of Prefabrication Adopted in India, if the building materials are concrete, steel or timber based system, the benefits of prefabricated building systems must be obvious. It is an industrialized way of construction, with the inbuilt advantages of:

- High capacity - enabling the understanding of important projects

- Factory made products

- Independent of unfavorable weather circumstances during construction

- Quality observation/surveillance system

- Shorter construction period - below half of conventional cast in-situ construction.

DOI:10.5121/civej.2016.3205 
Since the main goal of prefabrication is to consequence economy, enhancement in quality and speed in construction, the choice of proper materials for prefabrication is also a significant feature in the development of this technique. The use of locally existing materials with essential characteristics and also owing to their inherent characteristics such as easy workability/flexibility, light-weight, non-combustibility and thermal insulation, effect economy and enhanced quality may be tried in prefabrication.

In civil engineering projects, prefabrication saves engineering point in time on the construction site. This can be fundamental to the accomplishment of projects such as bridges and landslide galleries, where weather conditions may only permit short periods of construction. Prefabricated bridge systems and elements offer bridge designers and contractors considerable advantages in terms of construction time, safety, environmental impact, constructability, and cost.

Figure 1. shows the comparison between the In-situ buildings and the proposed prefabricated buildings in construction fields.

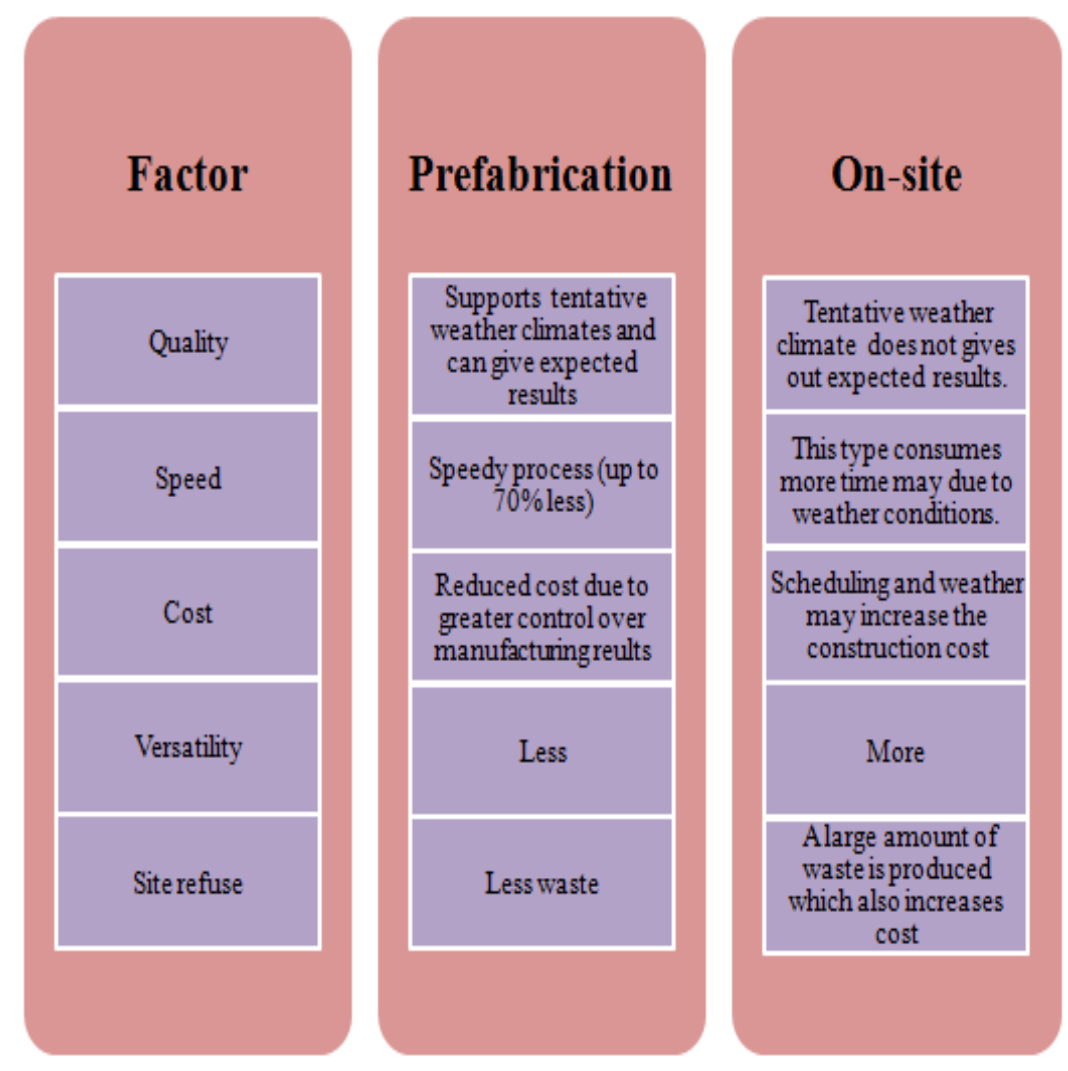

Figure 1.1. Advantages of Prefabricated buildings over In-situ buildings

\subsection{Time}

Prefabrication can give way to save timings through the capability to carry out work concurrently on-site and off-site, in addition to helping with enhanced management with different traders. Additionally, less onsite performance, such as scaffolding, is regularly concerned. Regionally, the capacity to stay away from weather impacts can lessen construction time. Site conditions issue considerably in the facility of prefabrication to crash schedule. 
Currently, Two-thirds of Construction firms which uses modularization /prefabrication observed that prefabrication reduces the schedule of the project up to $35 \%$ i.e., four weeks or more.

On difficult/complex projects to coordinate the use of prefabrication and modularization, extra time may be used up in the design phase. On the other hand, the time saved onsite normally reduces the whole project schedule.

\subsection{Cost}

As an outcome of using prefabrication/modularization, vendor report of project cost decrease ranging from $2 \%$ to $40 \%$. A number of owners for these cheap costs consist of:

- Possibly Local labors are very expensive or inefficient for onsite work.

- Costly delays may occur due to unfavorable onsite environmentand weather troubles.

cost related with onsite infrastructure and overhead can be reduced by relocating some or all of the work to an off-site locality as some owners statement . Furthermore they state that smaller number of workers onsite render to fewer costs for housing, scheduling onsite work and additional onsite logistics.

For prefabrication /modularization, labor costs can be a vital factor. Owners point out that prefabrication/modularization offers a less pricey alternative for very high local labor cost areas.

\subsection{Quality}

Quality control forms a primary part of precast construction. A proficient quality method is most significant in the accumulation making of precast components in every project. The quality control system implemented in a precast industrial unit is discussed in this study.

The precast industrial unit is set up for the production of large scale buildings.Processes in the precast production are proposed with respect to the quality control procedures in the quality inspection plan. The standard tests like concerned roles of inspectors and corrective actions onsite are tinted. Serious issues pertaining to the quality and productivity of precast manufacture are reviewed. These consist of the quality of maintenance and staff, which possibly will potentially have an effect on the effectiveness of the quality system. Various considerations are supposed to also be given to develop the workflow and efficiency of the factory.

\section{NEED FOR STUDY}

In the current situation the construction of buildings are very difficult thing around the world due to over contest and necessities of client requirements.Quality of On-site buildings are mainly affected by several reasons like poor quality of materials, environmental factors, wastage of materials, etc.... This proposal will used to recognize factors for good quality of production/ construction at low cost. 
Civil Engineering and Urban Planning: An International Journal (CiVEJ) Vol.3, No.2, June 2016

\section{OBJECTIVES}

$>$ To Study on efficient deployment of Cost in Prefabricated and In-situ buildings.

To Study on efficient exploitation of Time in Prefabricated and In-situ buildings.

To Study on Quality of prefabricated and In-situ buildings.

Making a Study about the methodology adopted in the manufacturing of prefabrication construction.

$>$ Management of Resources in Prefab and In-situ construction using Software.

$>$ To study on comparison of Duration, Cost, and Quality of prefabricated and In-situ buildings.

\section{LITERATURE REVIEW}

Based on the Prefabrication literatures are collected. From the review various factors were recognized.The literatures together are being used as base for the further procedures in the project.

The author [1] Christabel M F Ho, Raymond W M Wong., emphasizes that

- Mass production prefabricated building components (precast façade, precast stair flight, drywall and semi-precast floor planking) reduce cost and save time, with added advantage of taking some of the most dirty and awesome work out of the process.

- Faster erection capabilities and fewer manpower requirements make prefabrication the most viable option for public housing construction in Hong Kong.

- According to the study carried out by Tam (2002), there could be a 43 percent reduction in site labor consumption if there is a shift from the in-situ site casting to prefabrication design.

At the same time, prefabrication offers clients better performance to fulfill all requirements, such as:

- Opportunities for good architecture

- Fire resistant material

- Healthy buildings

- Reduced energy consumption through the ability to store heat in the concrete mass

- Environmentally friendly way of building with optimum use of materials, recycling of waste products, less noise and dust etc.

The authors Linda Brock, James Brown [2] stated that,

- In Canada, manufactured housing simply means that 85 percent or more of the construction is completed in a factory.

- In fact, 24 percent of new housing starts in 1996 were manufactured-mobile houses; only 2 percent to 3 percent were other prefabricated styles (such as modular housing).

- In the same year in Canada, all styles of prefabricated homes represented only 7.5 percent of the market, with two-thirds of these homes being single modules. 
Shri P K Adlakha, Shri H C Puri [3] describes prefabrication as In India, adoption of prefabrication building techniques has many merits in the context of availability of materials, labor and technical skills. Advantages of prefabrication are:

- In prefabricated construction, as the components are readymade, self supporting, shuttering and scaffolding is eliminated with a saving in shuttering cost.

- In traditional construction, the repetitive use of shuttering is limited, as it gets damaged due to frequent cutting, nailing etc. On the other hand, the mould for the precast components can be used for large number of repetitions thereby reducing, the cost of the mould per unit.

- In prefabricated housing system, there is saving of time as the elements can be casted before hand during the course of foundations being laid and even after laying slab, the finishes and services can be done below the slab immediately. While in the conventional in-situ RCC slabs, due to props and shuttering, the work cannot be done, till they are removed. Saving of time means saving of money.

- In prefabricated construction, there is better quality control, shape and size of precast elements. Therefore, in structural design, full advantage of properties of cement and steel can be exploited.

- In precast construction, similar type of components is produced repeatedly, resulting in increased productivity and economy in cost too.

- In precast construction, the construction is not affected due to weather, rain, wind etc

\section{Methodology}

With the intention to get the details associated to prefabricated construction uses along with their safety procedure and different methods of production literature study and the study of codes and regulation were prepared. The flowchart below represents the methodology adopted for the proposed work. After reviewing the literature the industry/company where the work is to be adopted is identified. Then the data's from the industry/company are collected and analyzed.

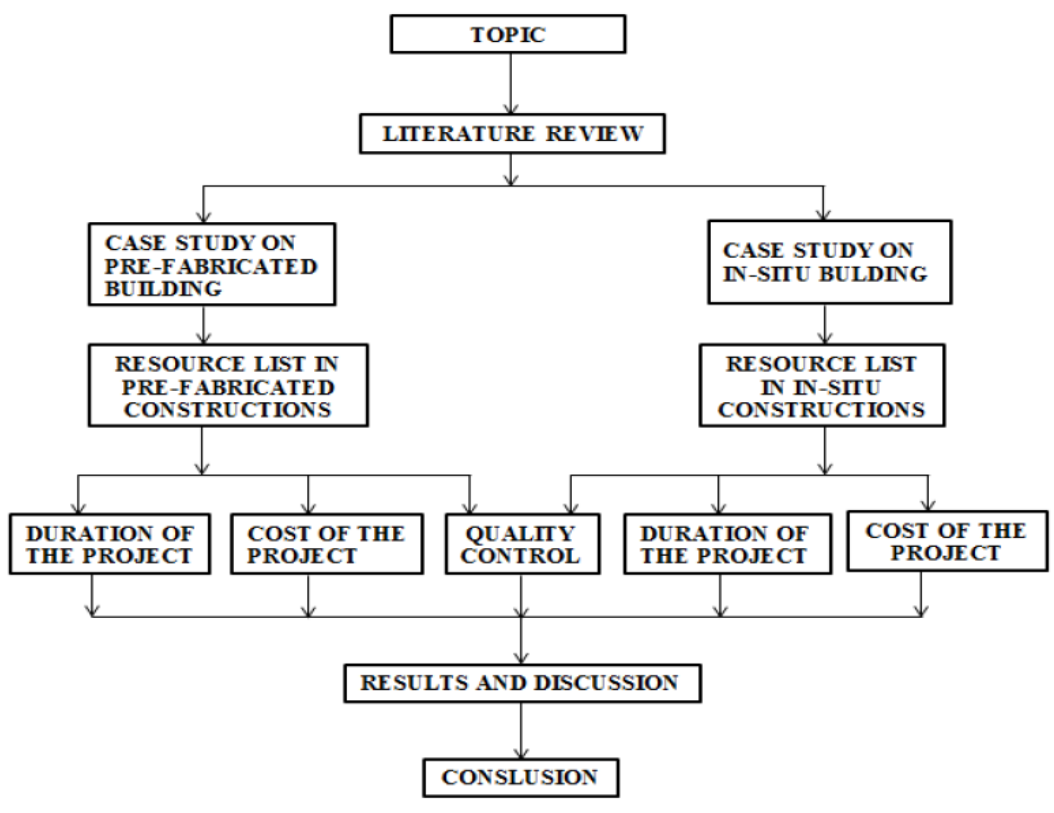

Figure 5.1. Work Flow Diagram 
Civil Engineering and Urban Planning: An International Journal (CiVEJ) Vol.3, No.2, June 2016

\section{Case Study On In-Situ Building}

Raj Associates has plans to build a multi-storeyed construction in the main area of the city. In building construction bunch of work packages and activities are mixed up. Making an effort to use the resource optimistically and also to lessen the time and cost. The activities for customizing different functional areas are declared as work packages and their relationship are specified.

\subsection{Stages Of Work}

$>$ General condition

$>$ Procurement of materials

$>$ Site preparation

$>$ Arrangement of site

$>$ Work on foundation

$>$ Erection of structures

$>$ Steel erection in $2 \& 3$ floor

$>$ Plumbing work

$>$ Work on roofs

$>$ Installation of windows

$>$ Finishing of building

$>$ Final clean-up and occupation

$>$ Works on floor

$>$ Final inspection

Table 6.1. Stages of Work for In-situ building

\begin{tabular}{|c|c|c|}
\hline Task name & Duration & Cost \\
\hline General condition & 14 days & रु $97,583.33$ \\
\hline Procurement of materials & 18 days & रु $179,000.00$ \\
\hline Site preparation & 13 days & 页 $117,000.00$ \\
\hline Arrangement of site & 17 days & रु $200,450.00$ \\
\hline Work on foundation & 46 days & रु $345,350.00$ \\
\hline Erection of structures & 24 days & रु $122,250.00$ \\
\hline Steel erection in $2 \& 3$ floor & 73 days & रु $405,550.00$ \\
\hline Plumbing work & 6 days & रु $58,200.00$ \\
\hline Work on roofs & 17 days & रु $92,600.00$ \\
\hline Installation of windows & 16 days & 卢 $106,400.00$ \\
\hline Finishing of building & 18 days & रु $62,850.00$ \\
\hline Final clean-up and occupation & 38 days & रु $203,950.00$ \\
\hline Works on floor & 22 days & रु $109,900.00$ \\
\hline Final inspection & 6 days & 页 $32,006.00$ \\
\hline TOTAL & 347 days & रु $2,096,189.33$ \\
\hline
\end{tabular}


Civil Engineering and Urban Planning: An International Journal (CiVEJ) Vol.3, No.2, June 2016

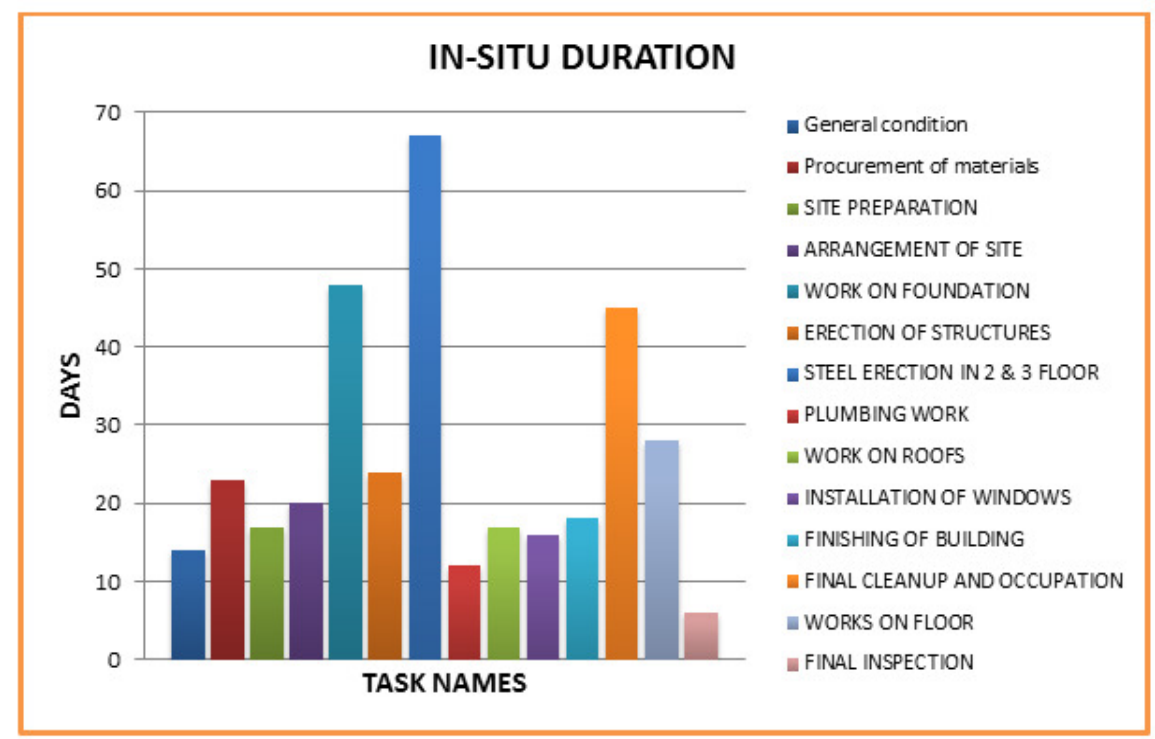

Figure 6.1. Duration of Project

Total duration of the Institutions building is 347 days.

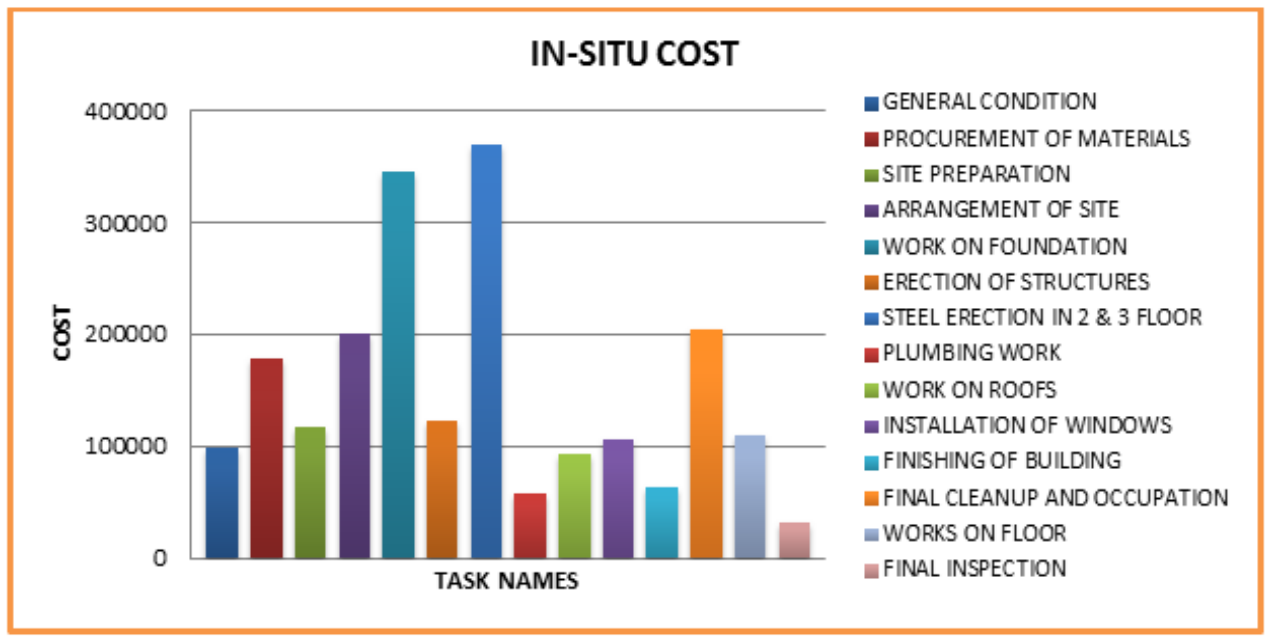

Figure 6.2. Cost of Project

Total budget of the In-situ building is Rs. 2,096,189.33/-

\section{Case Study On Prefabricated Building}

Teemage Precast Pvt. Ltd. plans to build a multi-storeyed construction in the main area of the city. In building construction bunch of work packages and activities are mixed up. Making an effort to use the resource optimistically and also to lessen the time and cost. The activities for customizing different functional areas are declared as work packages and their relationship are specified. 
Civil Engineering and Urban Planning: An International Journal (CiVEJ) Vol.3, No.2, June 2016

\subsection{Stages Of Work}

General condition

Procurement of materials

$>$ Site preparation

$>$ Arrangement of site

$>$ Work on foundation

$>$ Erection of structures

$>$ Steel erection in $2 \& 3$ floor

$>$ Plumbing work

$>$ Work on roofs

$>$ Installation of windows

$>$ Finishing of building

$>$ Final clean-up and occupation

$>$ Works on floor

$>$ Final inspection

Table 7.1. Stages of Work of prefabricated building

\begin{tabular}{|c|c|c|}
\hline Task Name & Duration & Cost \\
\hline General condition & 5 days & रु 38,500.00 \\
\hline Procurement of materials & 20 days & रु $147,750.00$ \\
\hline Site setting & 16 days & रु $87,500.00$ \\
\hline Site preparation & 6.5 days & रु $37,200.00$ \\
\hline Preparation of foundation & 4 days & रु $13,300.00$ \\
\hline Erect beams, columns for ground floor & 6 days & रु 294,800.00 \\
\hline Erection in first floor & 7 days & रु $431,400.00$ \\
\hline Staircase erection (b/w ground and 1 st floor) & 1 day & रु $147,600.00$ \\
\hline Erection in second floor & 7 days & रु $563,300.00$ \\
\hline Staircase erection (b/w 1 st and 2 nd floor) & 1 day & रु $147,100.00$ \\
\hline Erection in Third floor & 7 days & रु 709,000.00 \\
\hline Staircase erection (b/w 2 nd\& 3 rd floor) & 1 day & रु $147,100.00$ \\
\hline Erect parapet wall \& store room & 5 days & रु 437,700.00 \\
\hline Final clean-up and occupancy & 24.5 days & रु $116,675.00$ \\
\hline Flooring & 10.5 days & रु $34,425.00$ \\
\hline Final inspections & 5 days & रु $29,750.00$ \\
\hline TOTAL & 126.5days & रु $3,383,100.16$ \\
\hline
\end{tabular}


Civil Engineering and Urban Planning: An International Journal (CiVEJ) Vol.3, No.2, June 2016

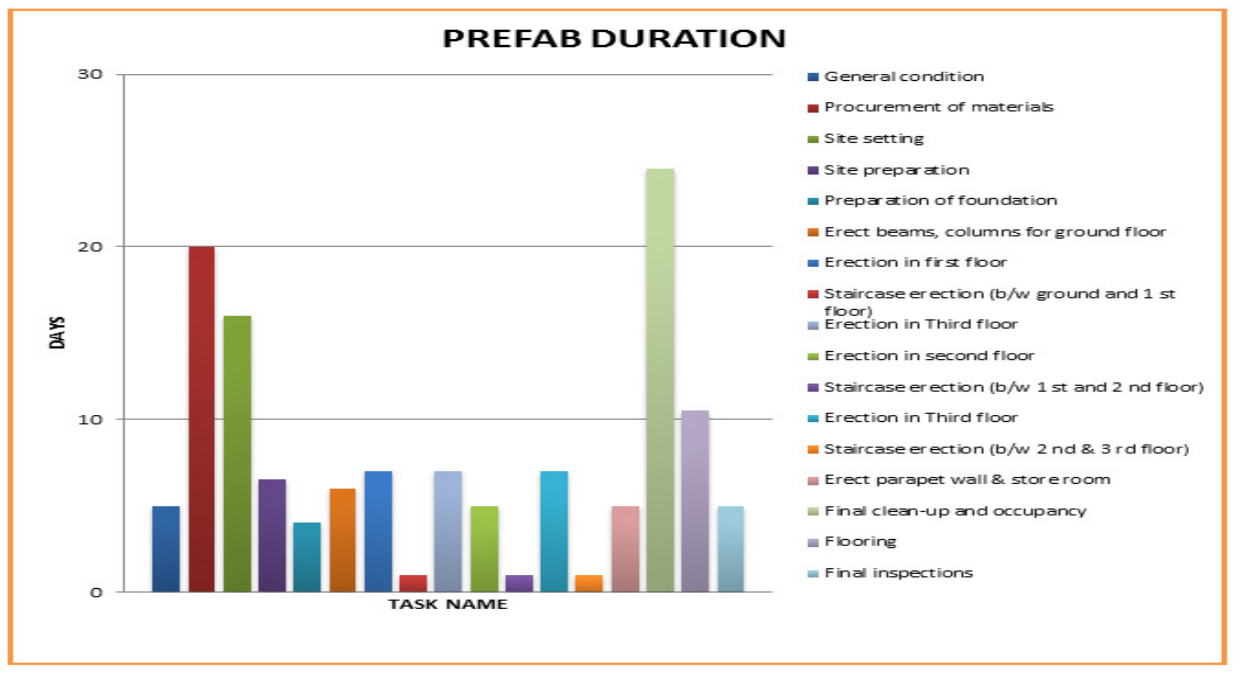

Figure 7.1.Duration of Prefabricated Building

Total duration of the prefabrication building is 126.5 days.

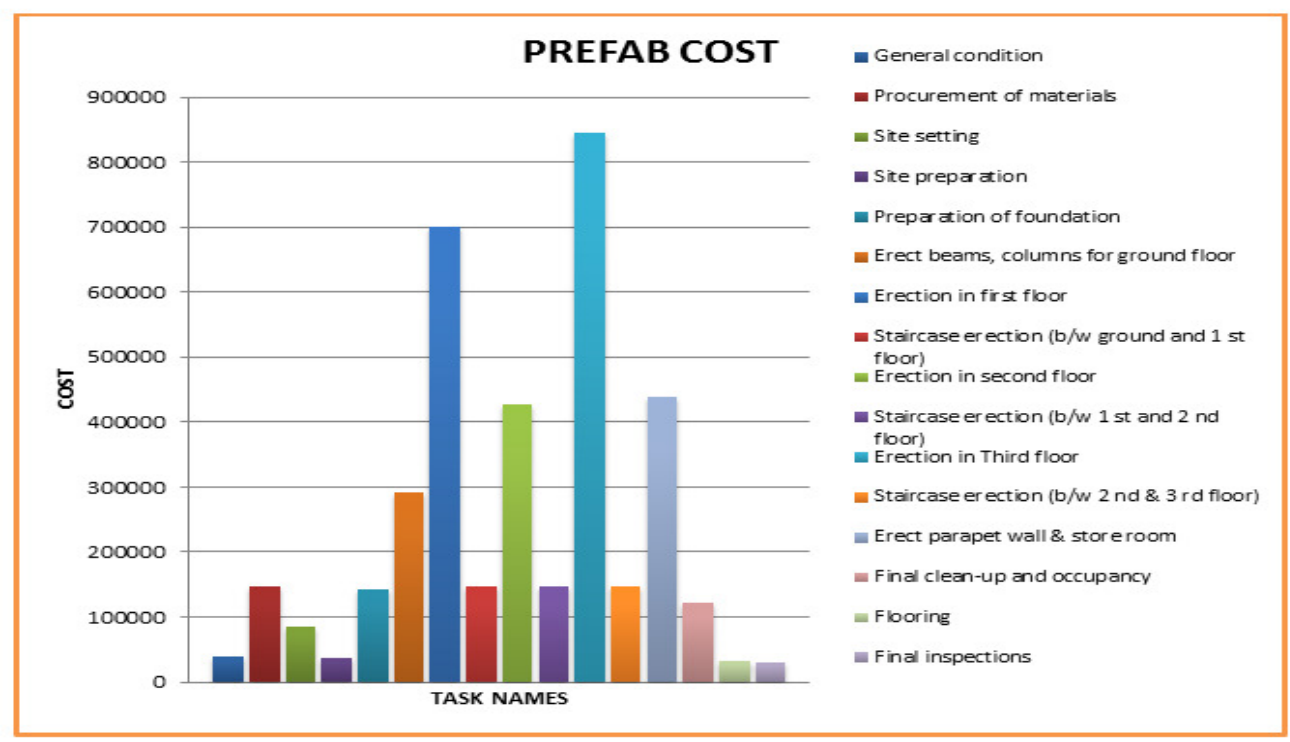

Figure 7.2.Cost of Prefabricated Building

Total budget of the Prefabrication building is Rs.3,383,100.16/-

\section{RESULT}

From the above case studies the following results are obtained.

- In this research the aim is to achieve low cost and time than In-situ construction. We obtain a time and cost utilization in prefabricated construction when compared to insitu construction. 
Civil Engineering and Urban Planning: An International Journal (CiVEJ) Vol.3, No.2, June 2016

- The time and duration requirements of the construction activities are determined from prefabricated construction and in-situ construction.

- Data's are analyzed by means of management software Tools like MS Project 2010.

- Project schedules are decreased by $75 \%$ compare than in-situ-construction.

- Project budget are increased by $31 \%$ compare than traditional construction like Insite.

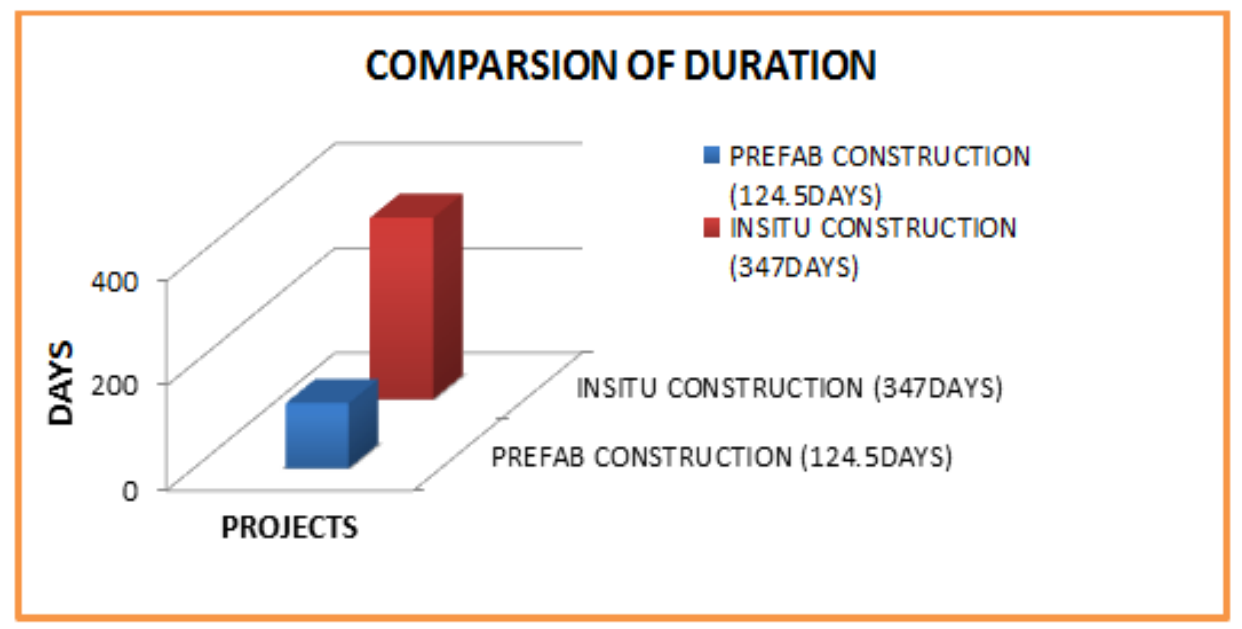

Figure 8.1.ComparisionOf Duration Between Pre Fabricated And Insitu

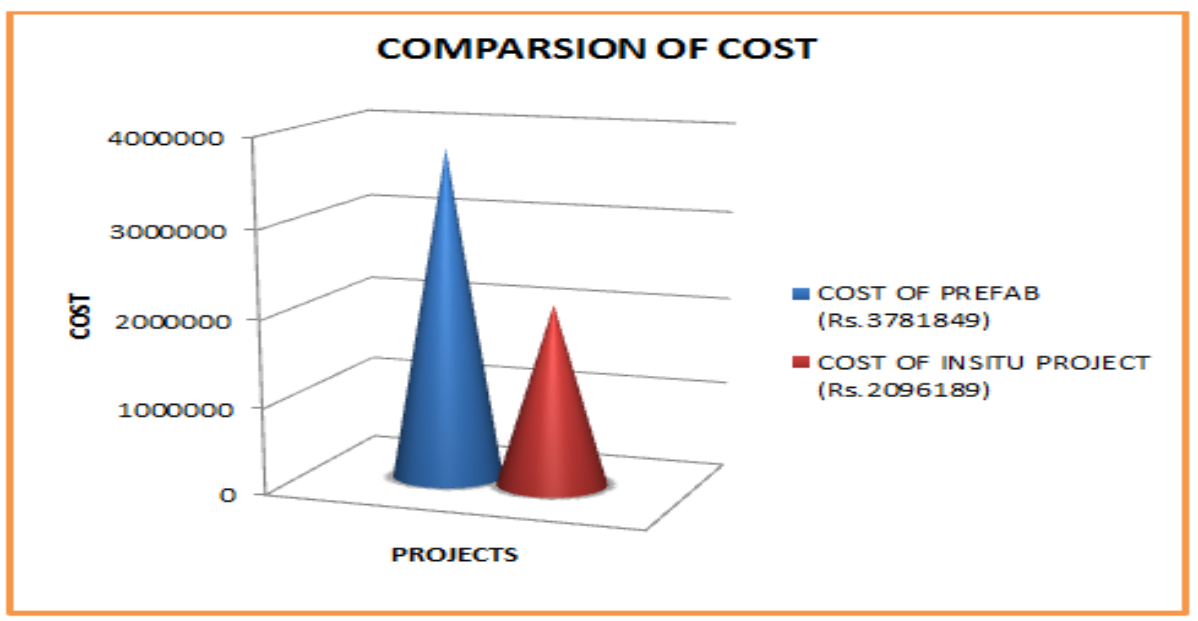

Figure 8.2.ComparisionOf Cost Between Pre Fabricated And Insitu

\section{SUGGESTIONS}

Based on the literatures and case study, the subsequent suggestions are used to get better performance of construction projects. 
- In civil engineering projects, prefabrication saves engineering point in time on the construction site. This can be fundamental to the accomplishment of projects such as bridges and landslide galleries, where weather conditions may only permit short periods of construction. Prefabricated bridge systems and elements offer bridge designers and contractors considerable advantages in terms of construction time, safety, environmental impact, constructability, and cost.

- Prefabrication can yield time savings through the ability to conduct work simultaneously on-site and off-site, as well as helping with better coordination among different traders. In addition, less onsite staging, such as scaffolding, is frequently involved. Regionally, the ability to avoid weather impacts can reduce construction time.

\section{REFERENCES}

[1] Christabel M F Ho and Raymond W M Wong., April (2002) "Prefabrication Building Construction System Adopted In Hong Kong” vol..pp383-390I.

[2] Linda Brock and James Brown APRIL (2003), "The Prefabricated House In The Twenty-First Century: What We Can Learn From Japan?" IE (I) Journal vol.6.

[3] Adlakha PK and Shri H C Puri., APRIL (2003) "Prefabrication Building Methodologies For Low Cost Housing" IE(I) Journal vol.84.

[4] Tam C. M (2002). "Impact on structure of labour market resulting from large-scale implementation of prefabrication" Advanced in Building Technology. Vol. 1. Pp399-403, Hong Kong.

[5] Andrew, M., \&Yali, P. (2012, April). The Rise of the Middle Class in Asian Emerging Markets. Retrieved February 18, 2013, from http://www.kpmg.com/cn/en/IssuesAndInsights/ArticlesPublications/Documents/Middle-Class-AsiaEmerging-Markets-201206-2.pdf

[6] Arno, C. (2012, May 11). CIVETS: New Global Marketing Opportunities in Emerging Economies. Retrieved February 17, 2013, from Search Engine Watch: http://searchenginewatch.com/article/2174005/CIVETS-New-Global-Marketing-Opportunities-inEmerging-Economies

[7] BBC. (2013, January 29). Vietnam profile. Retrieved February 21, 2013, from BBC: http://www.bbc.co.uk/news/world-asia-pacific-16567315

[8] Bowman, J. (2011, May). Vietnam - a marketer's overview. Warc Exclusive.

[9] Breu, M., Salsberg, B. S., \&Tú, H. T. (2010, August). Growing up fast: Vietnam discovers the consumer society. Retrieved February 18, 2013, from Mckinsey Quarterly: http://www.mckinseyquarterly.com/Growing_up_fast_Vietnam_discovers_the_consumer_society_26 55

[10] Chau, Q. (2013, January 8). Gloomy market to get darker. Retrieved February 21, 2013, from Vietnam Investment Review: http://www.vir.com.vn/news/business/property/gloomy-market-to-getdarker.html

[11] CIA. (2013, February 11). The World Factbook: Vietnam. Retrieved February 20, 2013, from CIA World Factbook: https://www.cia.gov/library/publications/the-world-factbook/geos/vm.html .

[12] Euromonitor. (2011, February 18). Doing Business and investing in Vietnam: challenges and opportunities. Retrieved March 2, 2013, from Euromonitor: http://blog.euromonitor.com/2011/02/doing-business-and-investing-in-vietnam-challenges-andopportunities.html

[13] Euromonitor International. (2008, February 4). The Next 11 emerging economies. Euromonitor International.

[14] Euromonitor International. (2013, January 25). Vietnam: Country Pulse. Euromonitor International.

[15] Franzoni, J. (2012, January 5). Modular Housing in Maryland. Retrieved February 28, 2013, from Commercial Real Estate Property News: http://realestatenewpa.blogspot.ca/2012/01/modularhousing-in-maryland.html

[16] Global Industry Analysts. (2012, March 2). Global Prefabricated Housing Market to Reach 829 Thousand Units by 2017, According to New Report by Global Industry Analysts Inc. Retrieved February3,2013,fromPRWeb: 
Civil Engineering and Urban Planning: An International Journal (CiVEJ) Vol.3, No.2, June 2016

http://www.prweb.com/releases/prefabricated_housing/manufactured_modular_home/prweb9246506. htm

[17] Global Property Guide. (2012, November 2). Vietnamese Housing Market's Amazing Slump. Retrieved February 22, 2013, from International business Times : http : // au.ibtimes.com / articles / 400748 / 20121102 / Vietnamese -housing-market-s-amazing slump.htm\#.USRE72d0RTo

[18] Industry Canada. (2010). Industry Canada. Retrieved February 3, 2013, from Data Tables: Sawmills and Wood Preservation(NAICS 3211): http://www.ic.gc.ca/cis-sic/cis-sic.nsf/IDE/cissic3211tabe.html

[19] Jeong, T. (2011, March 28). Korea: Trending towards Prefab? Retrieved February 28, 2013, from Canada Wood: http://canadawood.org/blog/?p=149 